\title{
FREE MOVEMENT OF PERSONS AND THE LEGAL SECURITY OF DOCUMENTS WITHIN THE EUROPEAN UNION
}

\author{
Mădălina cocoșATU* \\ Claudia Elena MARINICĂ ${ }^{* *}$
}

\begin{abstract}
The increase of international and European Union migration has led to increasing attention to the impact of Member States' legislation on the recognition, legal certainty and standardization of procedures for the movement of official documents, as part of the free movement of persons within the European Union. This article responds to European Union's needs by examining the extent to which the various regulations, in particular regulations having direct and immediate application, being long and complex and comprehensively governing some cross-border procedures that underline the recognition of official documents within the European Union. It is a fact that the Union facilitates and accelerates the cross-border application of aspects of the free movement of persons in private international law, encourages the simplification of the requirements for the presentation of certain official documents in EU, while strengthening the security of Union citizens' identity cards and residence documents etc. By using the historical and comparative method, the conclusions drawn from this analysis refer to the need to apply these legislative rules established due to the necessity to ensure legal certainty and predictability at Union level, but also offering to European citizens an attractive option compared to the classic variants of international law, the latter providing at times a more convincing and comprehensive legal certainty.
\end{abstract}

Keywords: administrative cooperation; EU law harmonization; citizen; recognition; public documents; legal security.

DOI: 53373 / REDS.2021.53.4.042

\section{INTRODUCTION}

The European Union's commitment to the adoption of a global order based on international law, aspiring to ensure peace, security, to respect human rights and sustainable development, is well known. Achieving these goals requires better global solutions, new rules based on international agreements, and also on multilateral cooperation with other global organizations. Off course, "the European Union (EU) has profiled itself as an important international actor in the fields of environmental policy, human rights and social economy. According to their declared attitudes and values, the EU and the alter-globalization movement have a lot in common"1.

\footnotetext{
* Associate professor Faculty of Public Administration, National School of Political Studies and Public Administration, Bucharest, Romania madalina.cocosatu@administratiepublica.eu

** PhD Assistant, Faculty of Public Administration, National School of Political Studies and Public Administration, Bucharest, Romania elena.marinica@administratiepublica.eu
} 
The core values of the EU are common ${ }^{2}$ to all Member States, they are an integral part of the daily life of European citizens, but we also share the view ${ }^{3}$ according to which the word "common" expresses the idea that these values and principles are not new, authentic, for the EU because they are stipulated as such by the constitutional provisions of the Member States and the agreement of sovereign states," but "they become values and principles" for all Member States.

The single market is perhaps the most important achievement of the EU, based on the four fundamental freedoms: the free movement of people, goods, services and capital.

\section{FREE MOVEMENT}

The core values of the EU are common to all Member States, they are an integral part of the daily life of European citizens, but we also agree with the opinion that free movement is an essential right of EU citizens ${ }^{4}$ and it must mean more than an abstract idea. It must become a reality in all Member States. [...] The creation of a European area of justice without internal borders strengthens the single market ${ }^{5}$. The rights of free movement and residence of citizens of the Union and the implementation of the area of freedom, security and justice in the European Union have led to the existence of a high degree of mobility in this area without borders, formed within the territory of the EU Member States.

Assuming that the free movement of persons is one of the four fundamental freedoms of the European Union and considering the content of the Stockholm Program, its main objective becomes to "build a Europe of the citizen" and to facilitate the access of EU citizens when capitalizing on the rights conferred on EU Member States, one of its effects is the free movement of documents within the EU, to support and promote the mobility of citizens and the legal security of their documents. It is true that "movement between Member States has become more ordinary over the past decades, and will become even more so. The ubiquity of English, the standardization of qualifications, and the existence of an internet-based global youth culture make it ever easier for the migrant to find a place in a host state and overcome national differences. [...] All of this is certainly the intention of EU policies"

${ }^{1}$ Rohrbacher, T.. The EU and the alter-globalisation Movement's actorness. Central European Journal of International \& Security Studies, (2012), 6(3-4), p. 345.

${ }^{2}$ Renucci, J. F., Tratat de drept european al drepturilor omului, Editura Hamangiu, București, 2009, p.7.

${ }^{3}$ Lefter C., Are the rules of the European Union public policy a reality? Juridical Tribune Volume 5, Issue 2, December 2015, p. 257.

${ }^{4}$ Craig P., de Búrca G., Dreptul Uniunii Europene. Comentarii, jurisprudență și doctrină, Ediția a-VI-a, Editura Hamangiu, București, 2017, pp. 886-888, 956-961.

${ }^{5}$ European Judicial Network in civil and commercial matters, Citizen's Guide to Cross-Border Civil Litigation in the European Union - Statement by Ms. Viviane Reding - Vice-President of the Committee on Justice, Fundamental Rights and Citizenship, p. 2.

${ }^{6}$ Davies G., (2021) European Union Citizenship and the sorting of Europe, Journal of European Integration, 43:1, 49-64, DOI: 10.1080/07036337.2020.1723577, pp. 56-57. 
In this context, using the historical and comparative method we analysed, in addition to national substantive law governing the recognition of content, legal effects and certainty of documents owned, and excluding also public and private international law, European Union law regulates the European dimension and the cross-border nature of official documents within the Union.

To ensure the free movement of official documents within the EU, to promote the free movement of EU citizens, it is necessary to adopt concrete measures to simplify existing administrative requirements related to the presentation in a Member State of certain official documents issued by the authorities of another Member State.

In pursuit of its objective - an area of freedom, security and justice, the EU must adopt, among other things, certain measures relating to judicial cooperation in civil matters having cross-border implications. This approach is the result following the repeated assessment of the practice of administrative authorities, which has indicated that the formalities that apply in connection with the acceptance of foreign public documents are quite rigorously applied.

Thus, over time, "due to the intensification of private legal relations between people from different states, the EU has felt the need to create common conflicting rules for Member States" and "the harmonization process, in some areas, has required the adoption of national legislation, and this could not but have repercussions on private international law"7.

It should be likewise emphasized that "the authenticity of a public document and the accuracy of its content are concepts related to the fact that the presumption of accuracy of a document follows only after establishing its authenticity. However, the presumption of accuracy of the content of a document is more closely linked to the fact that the signatory of the document is deemed a reliable source of information; a public authority"8.

It is considered that "in terms of cross-border use of documents, alternative means of certification and authentication requires global accession and uniform application" and the only instrument, outside the European Union, at international level, "which seems to be relatively close to achieving this is the 1961 Hague Convention by the introduction of the apostille" . However, many practical shortcomings were found in the application of the apostille ${ }^{10}$, which was nevertheless considered a genuine means of confirming the authenticity of foreign public documents.

\footnotetext{
${ }^{7}$ Mimoso M.J., Anjos M.d.R., Almeida A., The private international law communitarization, Juridical Tribune Volume 8, Issue 3, December 2018, p. 620.

${ }^{8}$ Van De Velden J., (London), The Use of Public Documents in The EU, Synthesis Report, British Institute of International and Comparative Law, July 2007, p.221.

9 Ibidem, p. 222.

${ }^{10}$ For more details see Cocoșatu M., Marinică C.E., (2020), International recognition of documents- a result of globalization and mobility of individuals, Revue Européenne du droit social no. 3 2020, pp.16-29.
} 
Whereas the number of citizens of the European Union working, studying or living in another Member State has increased considerably in the last decade ${ }^{11}$, they must present documents in one EU Member State that are issued in another. As in most cases, these documents are not automatically accepted but must be subject to an authentication process, which involves a series of verifications; this process was initially replaced by the apostille, which reduced only part of the stages of the previous administrative procedure, but did not it eliminate it, while supporting the need to maintain legal certainty and strong administrative cooperation between national authorities.

In the following, we will try presenting as an example a series of acts adopted at the regional level, inside the borders of the European Union, concerning sectoral policies, which aimed at facilitating the free movement of official documents, but also at the harmonization and standardization of legislation on certain types of documents and procedures.

\section{ADOPTION OF EUROPEAN UNION REGULATIONS TO SIMPLIFY THE PROCEDURES FOR THE RECOGNITION OF DOCUMENTS ISSUED ON THE TERRITORY OF THE MEMBER STATES}

We all agree that "The Union has adopted an important set of regulations dealing with international jurisdiction and the recognition of foreign decisions related to marriage law, including insolvency and maintenance obligations, divorce and determination of the applicable law to contractual and non-contractual obligations, to insolvency and maintenance obligations and currently also to succession"12. All of this also underline a circulation of documents used in such proceedings, raising the issue of their legal security.

First, at EU level, we emphasize the adoption of Regulation (EU) 2016/1191 on promoting the free movement of citizens through the simplification of the requirements for the presentation of certain official documents in the EU which ${ }^{13}$ reduces bureaucracy and the cost for citizens when presenting an official document issued by the authorities of one EU country, to the authorities of another EU country.

Regulation (EU) 2016/1191 considers that, at international level, EU Member States are in turn contracting parties to the Convention on the Suppression of the Re-

\footnotetext{
11 To over 12 million citizens.

12 Mimoso, M. J., \& Anjos, M. d. R. (2019). European Regulation of International Private Relations: The Emergence of a European Private International Law. Varazdin: Varazdin Development and Entrepreneurship Agency (VADEA), p. 245.

${ }^{13}$ Regulation (EU) 2016/1191 of the European Parliament and of the Council of July 6, 2016 on promoting the free movement of citizens by simplifying the requirements for the presentation of certain official documents in the European Union and amending Regulation (EU) No 1095/2010 1024/2012, published in OJ L 200, of 26.7.2016.
} 


\section{Revue europénnee du droit social}

legalization of Foreign Officials, signed in The Hague on October 5, $1961^{14}$, at the Hague Conference on Private International Law (the "Apostolic Convention"), which abolishes the requirement to legalize foreign public documents and simplifies the circulation of public documents issued by the Contracting Parties; but on the other hand, in the EU member states the principle of European mutual trust law also applies. Thus, it can be noted that the above-mentioned Regulation allows Member States to continue to use other existing solutions until the time of its entry into force, it allows the use of existing international conventions and treaties, but at the same time it ensures a set of Union rules concerning the simplification of the requirements for the presentation of certain official documents in the EU.

Before presenting some aspects regarding the role and scope of this Regulation, it should be clarified that its provisions are applicable from February 16, 2019, with some exceptions ${ }^{15}$.

Perhaps the most important regulation brought about by this European text is the elimination of the requirement for the application of the apostille ${ }^{16}$ and simplification of formalities for certified copies and translations. In regards to the scope, the Regulation shall apply in accordance with Article 2 "official documents issued by the authorities of a Member State in accordance with its national law which must be submitted to the authorities of another Member State and whose main purpose is to establish one or more the following: (a) birth; (b) the fact that a person is alive; (c) death; (d) the name; (e) marriage, including marital capacity and marital status; (f) divorce, legal separation or marriage annulment; (g) the registered partnership, including the ability to enter into a registered partnership and registered partnership status; (h) dissolution of a registered partnership, legal separation or cancellation of a registered partnership; (i) parentage; (j) adoption; (k) domicile and /or residence; (1) citizenship; (m) the absence of a criminal record, provided that such official documents are issued to a citizen of the Union by the authorities of the Member State of which he is a national, and the right to vote and to stand as a candidate in municipal elections and for the European Parliament.

As in the case of the apostille, the Regulation confirms the authenticity of the official document, not the recognition of its content or effects. Simultaneously, regarding the certified copies, it is provided that "EU countries may request the presentation of the original official document or a certified copy, but not both simultaneously, and if an EU country accepts the presentation of a certified copy in

\footnotetext{
${ }^{14}$ Available online at https://www.hcch.net/en/instruments/specialised-sections/apostille, accessed on 10.11.2020.

${ }^{15}$ Article 24 (2), which are applicable from February 16, 2017, Article 12 and Article 24 (3), which are applicable from February 16, 2018, and Article 22 and Article 24 (1), which are applicable from August 16, 2018.

${ }^{16}$ For more information see Schlauß, S., The EU Regulation on Public Documents: A first step towards the abolition of the Apostille in the EU (2020) ERA Forum, 21 (1), pp. 117-128.
} 
exchange for the official document, it must accept a certified copy made in another EU country"17.

Regarding the situation of translations, "the EU country where the official document is presented may not request the presentation of the translation of the official document if it is written in one of the official languages of that EU country or in an unofficial language that can be accepted by that country the EU"18 or if the official document is accompanied by a standard multilingual form. The Regulation offers standard multilingual forms in all EU languages (optional), which provides assistance in translating official documents.

It is important to point out that, according to the Regulation, "official documents" means: "(a) documents emanating from an authority or an official of a state jurisdiction, including those emanating from the public prosecutor's office, from a clerk or a bailiff; (b) administrative documents; (c) notarial deeds; (d) official certificates deposited on privately signed documents, such as official certificates on registration entries, investment visas with a certain date and signature legalizations; (e) documents drawn up by the diplomatic or consular agents of a Member State, operating in the territory of any State in their official capacity, if those documents are to be presented in the territory of another Member State or to the diplomatic or consular agents of a ate another Member State, which operates in the territory of a third country"19.

"Authority" means a public authority of a Member State or an entity acting in an official capacity which is authorized under national law to issue or receive an official document covered by this Regulation or a certified copy and, last but not least, by "legalization", a formality certifying the authenticity of the signature of a person holding an official position, the quality in which the signatory of the document acted and, if applicable, the identity of the seal or stamp affixed to the document, respectively. Of course, the use of the term "formality" in various ways suggests on the one hand the addition of the certificate provided by the Apostolic Convention ("similar formality") or the requirement to provide certified copies and translations of official documents ("other formalities").

To combat the phenomenon of falsification of official documents, especially in the context of simplifying these recognition procedures outside the issuing state, a co-operation mechanism has been set up between EU authorities, based on the Internal Market Information System - "IMI," Established by Regulation (EU) no. 1024/2012, where "the authorities of a Member State in which an official document

\footnotetext{
17 See the European Union website, available online at https:/leur-lex.europa.eu/legalcontent/RO/TXT/?uri=legissum:230101_2.

18 Ibidem.

${ }^{19}$ Art.3 of Regulation (EU) 2016/1191 of the European Parliament and of the Council of July 6, 2016 on promoting the free movement of citizens by simplifying the requirements for the presentation of certain official documents in the European Union and amending Regulation (EU) no. 1024/2012, published in OJ L 200, of 26.7.2016.
} 
or certified copy thereof is presented have reasonable doubts as to the authenticity of that official document or a certified copy thereof." (Article 14 para. 1).

By this Regulation, the European Commission has established that it is necessary to evaluate the application of its provisions at the latest every 3 years (until February 16, 2024), by drawing up a report and proposals for amendments and, last but not least, to make an analysis regarding the opportunity to extend the provisions of the Regulation to other categories of official documents. The Commission will also submit to the EU institutions an evaluation report on the appropriateness of extending its scope to "(i) official documents relating to the legal status and representation of a company or to another undertaking, (ii) diplomas, certificates and other evidence of formal qualifications; and (iii) official documents attesting to an officially recognized disability" ${ }^{20}$.

Noteworthy, although it will become applicable from August 2, 2021, is Regulation (EU) 2019/1157 of June 20, 2019 on enhancing the security of Union citizens' identity cards and residence documents issued to Union citizens, and allowing their family members to exercise their right to free movement ${ }^{21}$. The preamble to this regulation refers to "increasing the level of security in a world of mobility", with the European Commission stressing that "the security of travel and identity documents is essential when it is necessary to establish a person's identity with certainty". Why was this regulation instituted? Because it is necessary to include security features in the identity cards and residence permits of family members who are not nationals of a Member State in order to verify that the document is authentic and to establish a person's identity in order to make a more secure use of these documents in the Union and to provide sufficient guarantees to public authorities and private entities and to ensure that EU citizens have confidence in the authenticity of identity cards.

The Regulation states that its provisions comply with the obligations set out in the Charter of Fundamental Rights of the European Union and the United Nations Convention on the Rights of Persons with Disabilities, as Member States are encouraged to work "to integrate additional features that make identity cards more accessible and easier to use for people with disabilities, such as the visually impaired. Member states are to explore the use of solutions, such as mobile recording devices, for the issuance of identity cards to persons who are unable to travel to the authorities responsible for issuing identity cards" ${ }^{\prime 22}$.

This ensures that the exercising of this right by EU citizens is facilitated and recognised. "The right to free movement and the rights inherent in this exercise, but harmonization should not go beyond what is necessary to remedy the shortcomings of the current documents" 23 .

\footnotetext{
${ }^{20}$ Article 26 paragraph (1) of the Regulation.

${ }^{21}$ Published in Official Journal of the European Union L 188/67 of 12.07.2019, pp. 67-78.

22 Ibidem.

${ }^{23}$ Ibidem.
} 
The history of harmonization in the field of private international law it is written considering that "the beginning of the process of European harmonization of the rules of private international law in the field of family dates back to 20 years ago, when the Council recommended to the Member States the ratification of the Brussels Convention of 28 May 1998 on jurisdiction, recognition, and enforcement of judgements in matrimonial matters" 24 .

As an effect of the free movement of persons, having the goal of obtaining a unitary legislative response in family law at European level, a significant example is offered by Regulation (EC) no. Regulation (EC) No 2201/2003 (known as "Brussels II bis") on International Jurisdiction and the Recognition and Enforcement of Foreign Judgements in Matrimonial Matters and Parental Liability, repealing Regulation (EC) No 2201/2003 (known as "Brussels II a") 1347/2000, which presupposes the existence of an element of extraneousness, with effects on the family, the rights and obligations of the two spouses, the child interests protection and the patrimony acquired during the marriage, considering it appropriate having only one instrument in matters of divorce and parental responsibility. The Regulation recognizes fundamental rights and respects the principles inscribed in the EU Charter, in particular the fundamental rights of the child as the 24 article of the Charter rules.

Subsequently, Regulation (EU) no. 1259/2010 implementing a form of enhanced cooperation in the area of the law applicable to divorce and legal separation (known as "Rome III") ${ }^{25}$, through the carrying out of enhanced cooperation in the field of the right to cooperation applicable to divorce and legal separation. It "should establish a clear and comprehensive legal framework for the law applicable to divorce and legal separation in the participating Member States, guarantee citizens appropriate legal security, predictability and flexibility solutions and prevent divorce from one of the spouses. Before the other, the procedure is subject to a certain law, which he considers more favourable to his interests" ${ }^{26}$.

It can be stated that the concern of the European Union for the formation of a European legislation of the family law, with common denominators, considering the appearance in 2016 of new regulations such as Regulation (EU) 2016/Council Regulation (EC) No 1103 of June 24, 2016 implementing enhanced cooperation in the fields of jurisdiction, applicable law and the recognition and enforcement of judgements in matrimonial matters and Council Regulation (EU) 2016/1104 of June 24, 2016 implementing application of enhanced cooperation in the field of

${ }^{24}$ Damascelli, D. (2019). Applicable law, jurisdiction, and recognition of decisions in matters relating to property regimes of spouses and partners in european and italian private international law. Trusts \& Trustees, 25(1), 6-16, p.6.

${ }^{25}$ The Rome III Regulation applies to legal proceedings and agreements referred to in Article 5 of the Regulation and concluded on June 21, 2012 in 16 Member States (Belgium, Bulgaria, Germany, Spain, France, Italy, Latvia, Luxembourg, Hungary, Malta, Austria, Portugal, Romania and Slovenia, Lithuania and Greece).

26 Available online at https://eur-lex.europa.eu/legal-content/RO/TXT/?uri=CELEX\%3A32010R1259, accessed on 25.02.2021. 
jurisdiction, applicable law and the recognition and enforcement of judgements on the property-related consequences in the case of registered partnerships. The need for these legislative instruments is justified by the large number of properties owned by persons resident in another Member State, by the large number of marriages with cross-border implications which, in turn, end in the European Union, either through divorce or the death of one of the spouses and for whom there is no adequate international or supranational legal framework to resolve these situations, especially since the rules of private and national law in each Member State are sometimes extremely different.

To comply with the principle of proportionality established by the EU Treaties, only aspects of private international law are regulated and not aspects of substantive law in order to eliminate obstacles that may affect the freedoms of the EU in cases with a cross-border impact, to ensure legal certainty and predictability.

Regulation (EU) 2016/1103 and Regulation (EU) 2016/1104 are applicable from January 29, 2019, with some exceptions ${ }^{27}$ and respect the fundamental rights and principles recognized by the Charter, such as respect for private and family life, the right to marry and the right to find a family respecting the national law, the right to property, the principle of non-discrimination and the right to effective attack and a fair trial. By these regulations the EU established a global or common regulation of the practices of all aspects of private international law related to the economic consequences of marriages and registered unions.

The latter mention the free movement of authentic instruments and judgements regarding matrimonial property regimes and the property consequences of registered partnerships in order to obtain mutual recognition based on the integration of EU Member States. This means that these documents are recognized without any special procedure, have the same probative value and the same presumption of authenticity and enforceability as in their countries of origin and guarantee their acceptance for free movement, given the importance of the documents for matrimonial property regimes and the property effects of registered partnerships.

It is true that "although its application requires that the practitioner in law and other legal operators face a difficult challenge that requires specific training and technical tools for its implementation. There is no doubt that EU Regulation 2016/1103 will have a strong impact on the life of marriages with an international or cross-border element, which are increasingly common among EU citizens" 28 .

In the field of family law, namely inheritance law, with an impact on the mobility of citizens and on the recognition and legal security of documents issued, is included Regulation (EU) No.650 of July 4, 2012 on jurisdiction, applicable law, recognition, and enforcement of judgements and acceptance and enforcement of authentic instruments of succession and the creation of a European Certificate of

${ }^{27}$ With the exception of Articles 63 and 64, which apply from April 29, 2018, and Articles 65, 66 and 67, which apply from July 29, 2016.

${ }^{28}$ Vallejo, A. M. P. (2020). Ley aplicable y competencial judicial internacional en El Reglamento (UE) 2016/1103 sobre regímenes económicos matrimoniales. Anales De Derecho, 38(1), 1-19, p.17. 
Succession $^{29}$, which facilitates the free movement of persons within the EU as well as respect for the rights of Union citizens in the context of cross-border succession. Regulation no. 650/2012 entered into force on August 16, 2012 and applies to open successions starting with August 17, 2015.

The regulation is based on the European Commission's statistics according to which, annually, $10 \%$ of the total successions in the European Union are crossborder ${ }^{30}$, and for this reason it was considered necessary to simplify the procedures for establishing the inheritance and avoid disputes between the beneficiaries of the succession, but also as to establish measures for better functioning of the internal market, to ensure compatibility of conflict of laws rules and competencies in the Member States, to ensure legal certainty but also a high degree of predictability for citizens.

The Regulation states that "the proper functioning of the internal market should be facilitated by the removal of obstacles to the free movement of persons who currently face difficulties in exercising their rights in the context of a succession of foreign property. In the European area of justice, citizens must be able to organize their succession in advance. The rights of heirs and legatees, of other persons close to the deceased, as well as of the creditors of the succession, must be effectively guaranteed".

The above-mentioned regulation is based on the rights recognized by the Charter of Fundamental Rights of the European Union. Its provisions must be applied in a much faster and more effective and perhaps even more efficient way, while respecting the subsidiarity and proportionality principles.

Its main goal is the recognition of judgements given in EU Member States in the field of succession (mutual recogniton), being directly applicable in the Member States $^{31}$, in which the rules of private international law or, as the case may be, of other conventions shall be observed and further applied. The Regulation establishes the Member State is responsible for dealing with succession, applicable national law, enforcement and recognition throughout the EU, based on the European Certificate of Succession.

The general connecting factor between succession and the Member State ${ }^{32}$ is determined by the habitual residence ${ }^{33}$ of the deceased at the date of death. Ordinary residence is a basic notion of European law, "a constant of the decision on the applicable law and of the jurisdiction" 34 , "its purpose being to support the effective

${ }^{29}$ In 2014, a Regulation implementing the Succession Regulation was adopted, setting out many forms, in particular the European Certificate of Succession application form.

${ }^{30}$ The data for $10 \%$ predate the period of adoption of this regulation, so it is estimated that this percentage is currently significantly higher.

${ }^{31}$ Except for countries such as the United Kingdom, Ireland and Denmark.

${ }^{32}$ In which jurisdiction is exercised and where the applicable law is decided.

${ }^{33}$ Aniţei, N. (2017). How do we qualify primarily the concept of "residence" of the natural person in Romanian private international law? Juridical Tribune Journal = Tribuna Juridica, 7(2), 147-159.

${ }^{34}$ Jugastru C., „Reședința obișnuită” în contextual regimurilor matrimonial europene. Regulamentul (UE) 2016/1103, p. 1, article available online at https://www.universuljuridic.ro/resedinta-obisnuita-incontextul-regimurilor-matrimoniale-europene-regulamentul-ue-2016-1103/, accessed on 01.11.2020. 
capitalization of the interests of private individuals, beyond national borders. Romanian private international law is also following suit in regards to European normative acts, giving up the domicile in the effects of marriage" ${ }^{35}$. This criterion is a new element that encourages the mobility of citizens within the European Union and their integration into the Member State in which they reside, eliminating any possible discrimination on grounds of nationality. The right to choose the applicable law confers an enhanced autonomy to the citizens, the limitation to the status of citizens of a state ensuring the function of public order inherent to the right of succession, as well as the protection of family members. Also, to ensure the legal security of the citizens and for them to benefit from the advantages offered by the internal market, it allows to have advanced information about the applicable law and to organize the succession by choosing the law applicable to their succession.

The Regulation implements a European Certificate of Succession but it is not binding. The creation of this certificate is due to the necessity and determination to support the citizen, so the beneficiary of the succession is able to solve it irrespective of the foreign property aspect within the EU, "in a fast, simple and effective way, should be able to easily prove status and rights and competences in another Member State".

The European Certificate of Succession does not replace internal documents used for similar purposes in the Member States. To comply with the subsidiarity principle, the certificate must not replace internal documents that may exist for similar purposes in the Member States.

However, it is recommended to clarify that it should not be understood that with this European regulation there is also a European public order of succession, that there are common principles or a European law on successions, especially if we look at the provisions of Article 35 of the Regulation. It is stated that "the application of a provision of the law of any State specified in this Regulation may be refused only if such an application is manifestly incompatible with the public policy (public order) of the forum". It should be considerred that we can speak of a private international law on inheritance, which is found in the above-mentioned regulation.

There are voices ${ }^{36}$ saying that "what should have been a rather legal-technical regulation in the interest of European citizens is becoming more and more an open battleground where a mounting conflict is to be decided about the limits of a Member State's sovereignty and, consequently, the competence of its national judiciary and public officials such as land registers and notaries", considering that the gap "in European effet utile ${ }^{37}$ will have to be filled by a national pratique utile, in the interest of European citizens confronted with an international succession who were supposed

${ }^{35}$ Ibidem, p.3.

${ }^{36}$ Sjef, v. E. (2020). Inheritance certificates and EU law: Less european ",ffet utile" implies more national "pratique utile". European Property Law Journal, 9(2-3), 67-72.

${ }^{37}$ For more details see: C-218/16 - Kubicka Case (12 october 2017), C-20/17 - Oberle Case (21June 2018), C-80/19 - E.E. Case (16 July 2020). 
to have been freed from such legal complexities, and in the general interest to combat illegal real estate transactions and money laundering".

Still "the document has the merit of reducing a maximum of conflicts of laws, while accelerating procedures and providing legal certainty for the clients. Even if the exceptions and issues are numerous, it is up to practitioners to anticipate possible abuses and aberrations and publicize jurisdiction (al) choice of law"38. The ECS's creation is placing "the authenticated deed at the heart of an area of justice, freedom, and security aimed at facilitating everyday life of European citizens".

\section{CONCLUSIONS}

Therefore, regulations that have been created at EU level, in the field of free movement of persons and official documents within it should not be seen as regulations that eliminate or restrict other existing regulations at international level, but rather should be seen as a complement to the arrangements for providing citizens with similar formalities applicable between Member States.

Respect for and application of the principle of the priority of European law over national law means that European regulations take precedence over other agreements or understandings to which Member States are parties and concerning matters covered by those regulations, regarding matters falling within their scope; within the limits provided by them.

Following a deeper analysis on the rules of legislative technique, it can be concluded that regulations must be simple, uniform, clear and easy to apply to facilitate the mobility of documents and persons, to provide protection to stakeholders and help increase their effectiveness.

These simple, clear, uniform and easy-to-apply rules are necessary in order to ensure legal certainty and the predictability of rules established at EU level, to implement comprehensive regulations on private international law, and to guarantee legal certainty of those to whom these provisions apply.

Time will tell whether these regulations, with the advantages of standardizing and using the same specialty language, will be considered by citizens as an attractive option compared to the classic ones, which can sometimes provide a more convincing and comprehensive legal certainty. In addition, all aspects of the principles of legal certainty governing the preparation and circulation of documents required of interested parties must be taken into account.

These regional European legislative measures within the European Union ensure that citizens exercise their rights more effectively within the single market, given that legal certainty is one of the core values in the field of human rights. The freedom to choose the applicable law is offered to citizens and the possibility of

\footnotetext{
${ }^{38}$ Devaux, A. (2013). The european regulations on succession of july 2012: A path towards the end of the succession conflicts of law in europe, or not? The International Lawyer, 47(2), 229-248.
} 
organizing legal relations give the law of the European Union that preventive character, with an increased efficiency in respecting and protecting the citizen, in ensuring equality in legal relations, eliminating any form of discrimination and, last but not least, ensuring the safety of the civil circuit.

It is easy to understand that encouraging the free movement of citizens by facilitating either, in the ideal scenario, the free movement of certain official documents within the Union or, in a less ideal scenario a more easily accessible procedure for the movement of documents between states can be executed much more effectively at the level of international organizations and lacks when it is done between two states. We make this statement in view of the fact that the role of regional and international organizations has increased considerably in recent decades that all states are members of one or more organizations as the context of globalization imposed the formation of alliances and reliance on cooperation and standardization of legislative regulations.

Bibliography:

\section{Books, articles}

1) Aniţei, N. (2017). How do we qualify primarily the concept of "residence" of the natural person in Romanian private international law? Juridical Tribune Journal = Tribuna Juridica, 7(2).

2) Cocoșatu M., Marinică C.E., (2020), International recognition of documents- a result of globalization and mobility of individuals, Revue Européenne du droit social no. 32020.

3) Craig P., de Búrca. G, Dreptul Uniunii Europene. Comentarii, jurisprudență și doctrină, Ediția a-VI-a, Editura Hamangiu, București, 2017.

4) Damascelli, D. (2019). Applicable law, jurisdiction, and recognition of decisions in matters relating to property regimes of spouses and partners in european and italian private international law. Trusts \& Trustees, 25(1), 6-16,

5) Davies G. (2021) European Union Citizenship and the sorting of Europe, Journal of European Integration, 43:1, 49-64, DOI: 10.1080/07036337.2020.1723577.

6) Devaux, A. (2013). The european regulations on succession of july 2012: A path towards the end of the succession conflicts of law in Europe, or not? The International Lawyer, 47(2).

7) Jugastru C., „Reședința obișnuită” în contextual regimurilor matrimonial europene. Regulamentul (UE) 2016/1103, article available online la https://www.universuljuridic.ro/resedinta-obisnuita-in-contextulregimurilor-matrimoniale-europene-regulamentul-ue-2016-1103/.

8) Lefter C., Are the rules of the European Union public policy a reality? Juridical Tribune Volume 5, Issue 2, December 2015.

9) Lefter C., Are the rules of the European Union public policy a reality? Juridical Tribune Volume 5, Issue 2, December 2015

10) Mimoso, M. J., \& Anjos, M. d. R. (2019). European Regulation of International Private Relations: The Emergence of a European Private International Law. Varazdin: Varazdin Development and Entrepreneurship Agency (VADEA).

11) Mimoso M.J, do Anjos R., Almeida A., The private international law communitarization, Juridical Tribune Volume 8, Issue 3, december 2018.

12) Renucci, J. F., Tratat de drept european al drepturilor omului, Editura Hamangiu, București, 2009.

13) Rohrbacher T., The EU and the alter-globalisation Movement's actorness. Central European Journal of International \& Security Studies, (2012), 6(3-4).

14) European Judicial Network in civil and commercial matters, Citizen's Guide to Cross-Border Civil Litigation in the European Union - Statement by Ms. Viviane Reding - Vice-President of the Committee on Justice, Fundamental Rights and Citizenship.

15) Schlauß, S., The EU Regulation on Public Documents: A first step towards the abolition of the Apostille in the EU (2020) ERA Forum, 21 (1).

16) Sjef, v. E. (2020). Inheritance certificates and EU law: Less european "effet utile" implies more national "pratique utile". European Property Law Journal, 9(2-3). 


\section{European Journal of Social Law}

17) Vallejo, A. M. P. (2020). Ley aplicable y competencial judicial internacional en El Reglamento (UE) 2016/1103 sobre regímenes económicos matrimoniales. Anales De Derecho, 38(1).

18) Van De Velden J., (London), The Use of Public Documents In The EU, Synthesis Report, British Institute of International and Comparative Law, July 2007.

\section{Legislation:}

$\checkmark$ Regulation (EC) no. Regulation (EC) No 2201/2003 ("Brussels Ila") on international jurisdiction and the recognition and enforcement of foreign judgments in matrimonial matters and the matters of parental responsibility, repealing Regulation (EC) No 2201/2003 1347/2000, published in OJ L 338, 23.12.2003.

$\checkmark$ Regulation (EU) no. 1259/2010 implementing a form of enhanced cooperation in the area of the law applicable to divorce and legal separation ("Rome III"), published in OJ L 343, 29.12.2010.

$\checkmark$ Regulation (EU) No 650 of July 4, 2012 on jurisdiction, applicable law, recognition and enforcement of judgements and acceptance and enforcement of authentic instruments of succession and on the creation of a European Certificate of Succession, published in OJ L 201, 27.07.2012.

$\checkmark$ Regulation (EU) 2016/1191 of the European Parliament and of the Council of July 6, 2016 on promoting the free movement of citizens by simplifying the requirements for the presentation of certain official documents in the European Union and amending Regulation (EU) No 1095/2010 1024/2012, published in OJ L 200, of 26.7.2016

$\checkmark$ Council Regulation (EU) 2016/1103 of June 24, 2016 implementing enhanced cooperation in the areas of jurisdiction, applicable law and the recognition and enforcement of judgments in matrimonial matters, published in OJ L 183, 08.07.2016.

$\checkmark$ Regulation (EU) 2019/1157 of the European Parliament and of the Council of June 20, 2019 on enhancing the security of Union citizens' identity cards and residence documents issued to citizens of the Union and their family members exercising their right to free movement, published in the Journal Official Journal of the European Union L 188/67 of 12.07.2019

$\checkmark$ Council Regulation (EU) 2016/1104 of June 24, 2016 implementing enhanced cooperation in the areas of jurisdiction, applicable law and the recognition and enforcement of judgments regarding the property consequences of registered partnerships, published in OJ L 183, 08.07.2016.

$\checkmark$ C-218/16 - Kubicka Case (12 october 2017), C-20/17 - Oberle Case (21June 2018), C-80/19 - E.E. Case (16 July 2020). 